\title{
MAKNA KEPATUTAN DAN KEWAJARAN BERKAITAN DENGAN TANGGUNG JAWAB SOSIAL PERUSAHAAN DALAM UNDANG - UNDANG NOMOR 40 TAHUN 2007 TENTANG PERSEROAN TERBATAS
}

\author{
Rachmad Robby Nugraha, Siti Hamidah, Moh. Fadli \\ Magister Kenotariatan Fakultas Hukum Universitas Brawijaya \\ Jl. MT. Haryono, Nomor 169. Malang \\ Email :Rachmadrobby@gmail.com
}

\begin{abstract}
: the purpose of the author of this article is to discuss the meaning of propriety and reasonableness in Article 74 paragraph (2) of Law Number 40 of 2007 concerning Limited Liability Companies (UUPT) on a corporate social responsibility agreement in the distribution. The method uses normative legal studies with legislative approaches, concepts, and case studies. The propriety meaning is conformity based on balance, meaning that it must fulfill the element of conformity with the situation or the balance between the company's ability to risk the activities of the company. Fairness is interpreted as something that should or should be done based on the order and the appropriate rules. Compliance and reasonableness are viewed from the point of view of the amount that is spent on the company's CSR must be in proportion and not contrary to the provisions of the legislation. Compliance and reasonableness are related to the number, objectives, and form of the agreement.
\end{abstract}

Keywords: Compliance, Fairness, Agreement, Legal Certainty, Corporate Social Responsibility.

\begin{abstract}
Abstrak:tujuanpenulisanartikeliniadalahuntukmembahasmaknakepatutan dan kewajaran pada Pasal 74 ayat (2) Undang-Undang Nomor 40 Tahun 2007 tentang Perseroan Terbatas (UUPT) terhadap sebuah perjanjian tanggung jawab sosial perusahaan dalam menyalurkan.Metodemenggunakankajian hukum normatifdenganpendekatanperundang-undangan, konsep, dan studikasus. Maknakepatutan ialah kesesuaian yang berdasarkan keseimbangan, artinyaharus memenuhi unsur kesesuaian dengan keadaan atau keseimbangan antara kemampuan perusahaan terhadap resiko kegiatan perusahaan. Kewajaran dimaknai hal yang seharusnya atau sudah selayaknya dilakukan berdasarkan ketentutan dan aturan-aturan yang sesuai. Kepatutan dan kewajaran dipandang dari sudut jumlah yakni pengeluaran yang dikeluarkan oleh CSR perusahaan haruslah sesuai proporsinya serta tidak bertentangan dengan ketentuan perundangan. Kepatutan dan kewajaranberkaitandenganjumlah, sasaran, dan bentukperjanjian.
\end{abstract}

Kata Kunci: Kepatutan, Kewajaran, Perjanjian, Kepastian Hukum, Tanggung Jawab Sosial Lingkungan Perusahaan.

Subjek hukum berbentuk badan hukum merupakan kumpulan manusia pribadi (natuurlijke persoon) dan termasuk pula kumpulan dari badan hukum yang pengaturannya sesuai menurut hukum yang berlaku (C.S.T Kansil \& Christine Kansil, 2013:10). Perusahaan atau perseroan (maatschap) yang diatur dalam Kitab Undang Undang Hukum Dagang (KUHD) dan UndangUndang Nomor 40 Tahun 2007 tentang Perseroan Terbatas (UUPT)merupakan badan hukum yang diakui sebagai subjek hukum. Sebagai subjek hukum yang berbentuk badan hukum, sebuah perusahaan atau perseroan juga memiliki hak dan kewajiban yang sama dengan subjek hukum orang pada umumnya.

Pemerintah mengatur mengenai batasan hak dan kewajiban subjek hukum yang berbentuk badan hukum perusahaan, mulaidari pengaturan pendiriannya, roda aktivitasnya, sampai berakhirnya suatu perseroan. Perusahaan juga 
memiliki hak, diantaranyahakuntuk mencari keuntungan dan menjalankan aktivitasnya yang berkedudukan di Indonesia. Salah satu kewajiban perusahaan adalah bertanggung jawab terhadap lingkungan sosial dan alam sekitarnya.

Pengaturan terhadap kewajiban perusahaan untuk melaksanakan tanggung jawab sosial dan lingkungan, tertuang pada Pasal 74 ayat (1) dan ayat (2) UUPT yang menjelaskan bahwasannya perseroan yang menjalankan kegiatan usahanya di bidang dan atau berkaitan dengan sumber daya alam wajib melaksanakan tanggung jawab Sosial dan Lingkungan, serta pada ayat selanjutnya menerangkan tanggung jawab sosial dan lingkungan tersebut merupakan kewajiban perseroan yang dianggarkan dan diperhitungkan oleh perusahaan tersebut dengan pelaksanaannya didasarkan pada kepatutan dan kewajaran. Landasan utama ini sebagai dasar pedoman didalam menjalankan kegiatan tanggung jawab sosial perusahaan, disisi lain negara dalam hal ini pemerintah mengeluarkan Peraturan Pemerintah dengan berupa PP Nomor 47 Tahun 2012 tentang Tanggung Jawab Sosial dan Lingkungan Perseroan Terbatas yang mengatur pelaksanaan lebih lanjut mengenai tata acara tanggung jawab sosial lingkungan secara internal perusahaan melalui aturan ini, yakni dengan menganggarkan dana tersebut yang disetujui dan disahkan dalam Rapat Umum Pemegang Saham (RUPS) perusahaan.

Bentuk tanggung jawab sosial perusahaan atau Corporatesocial Responsibility (CSR), dewasa ini memiliki bermacam-macam bentuk. Mulai dari melakukan kegitan yang bentuknya mengembangkan kesejahteraan masyarakat dan perbaikan lingkungan, dana untuk perawatan fasilitas umum, pengadaan besasiswa di bidang pendidikan, pemberian sumbangan untuk desa atau fasilitas masyarakat yang bersifat sosial dan berguna. Karena pada dasarnya, masyarakat dan lingkungan alam sekitarnya tetap berhak untuk mendapatkan kehidupan serta lingkungan yang baik, sebagai salah satu bentuk wujud kewajiban negara didalam mensejahterakan rakyat, seperti halnya yang tertuang pada Pasal 28 huruf $\mathrm{H}$ Undang - Undang Dasar Negara Kesatuan Republik Indonesia (UUD NKRI) Tahun 1945 berhak untuk hidup sejahtera lahir batin, bertempat tinggal, dan mendapatkan lingkungan hidup yang baik.

Bentuk kegiatan dalam pelaksanaan tanggung jawab sosial lingkungan dalam pelaksanaannya terbagi menjadi 2(dua) macam kegiatan, yaitu dengan cara kemitraan dan non kemitraan. Pelaksanaan tanggug jawab sosial lingkungan perusahaan dengan cara penyaluran kepada mitra - mitra atau yang menjadi sasaran langsung perusahaan, yang telah terikat kontrak atau perjanjian kerjasama sebelumnya. Dewasa ini, perkembangan bentuk tanggung jawab perusahaan melalui kemitraan banyak tersalurkan melalui yayasan - yayasan yang ditunjuk, maupun bentuk kerjasama dengan pemerintah setempat. Sedang bentuk tanggung jawab sosial perusahaan dengan cara non kemitraan ialah bentuk penyaluran bantuan atau tanggung jawab perusahaan dengan tidak mengikutsertakan penyalur lain seperti halnya yayasan, anak perusahaan, ataupun pihak yang telah ditunjuk maupun bersama - sama dengan pihak lainnya yang masih ada keterkaitannya dengan kepentingan perusahaan. Seperti halnya beberapa contoh bentuk atau upaya penyaluran tanggung jawab sosial perusahaan yang telah terlaksana di indonesia yakni secara kemitraan dan non kemitraan. Berdasarkan kemitraan seperti halnya bentuk pelaksanaan atas Penyaluran Bantuan CSR PT. Pertamina (Persero) dengan Pemerintah Kota Surabaya terkait dengan pembenahan dan penataan taman eks SPBU (Stasiun Pengisian Bahan Bakar Umum) di Jalan A. Yani Surabaya pada tahun pelaksanaan 2007 Nomor: 415.4/5774/ 436.5.4/2007, serta pelaksanaan non kemitraan yang terlaksana atas Penyaluran CSR dengan Hibah daerah tertuju pada wilayah Rumah Susun Jalan Urip Sumoharjo Surabaya dari PT. Pembangkitan Jawa-Bali (PJB) berupa Pembangunan Canopy di Foodcourt yang diwakili oleh Pemerintah Kota Surabaya. Tahun pelaksanaan 2009 Nomor 008.PJ/061/2009.

Merujuk kembali pada ketentuan Pasal 74 UUPT, maka kewajiban bagi perusahaan untuk melaksanakan tanggung jawab sosial lingkungan memang mutlak wajib dilaksanakan oleh setiap perseroan baik yang bentuknya swasta maupun berbentuk Badan Usaha Milik Negara (BUMN). Pada ayat (2) yang menyebutkan bahwasannya, didalam melaksanakan kegiatan CSR itu sendiri dilaksanakan dengan memperhatikan kepatutan dan kewajaran. Dalam hal memperhatikan kepatutan dan kewajaran, batasan dan perwujudan seperti apa yang menjadi tolak ukur untuk sebuah penyaluran CSR tersebut dianggap patut dan wajar oleh undang - undang, serta wujud yang 
dipersyaratkan sebagai patut dan wajar apabila tertuang didalam sebuah perjanjian yang tujuannya dengan maksud penyaluran CSR. Karena sesuai pada ketentuan Pasal 2 PP Nomor 47 Tahun 2012 tentang Tanggung Jawab Sosial dan Lingkungan Perseroan Terbatas apabila bentuk tanggung jawab perusahaan ini tidak terlaksana ataupun tidak dilaksanakan oleh sebuah perseroan, maka berlaku ancaman sanksi yang diberikan berdasarkan ketentuan peraturan perundang - undangan yang terkait. Pelaskanaan dari bentuk tanggung jawab ini menurut Pasal 4 dilakukan oleh dalam hal ini Direksi yang telah mendapatkan persetujuan daripada dewan komisaris maupun persetujuan oleh Rapat Umum Pemegang Saham (RUPS), dimana pada pelaksanaannya, bentuk tanggung jawab perusahaan ini diperoleh dan dicatatkan sebagai pengeluaran perusahaan yang tertuang pada anggaran perusahaan.

Pengaturan terkait penyaluran dan sistematika pelaksanaan CSR itu sendiri di Indonesia masih belum tertuang didalam sebuah regulasi yang mengatur secara mendetail, terkait bagaimana bentukan dari penyaluran itu sendiri. Bagaimana penyaluran daripada tanggung jawab sosial perusahaan terkait dengan keikutsertaannya didalam melaksanakan CSR dengan mengacu pada tata cara pelaksanaan CSR yang baik dan benar berdasarkan tinjauan tolak ukur dari sudut jumlah atau besarannya, sasarannya, maupun bentuknya. Dalam hal belum adanya kepastian hukum terkait akibat hukum apabila kepatutan dan kewajaran didalam melaksanakan tanggung jawab sosial perusahaan yang tertuang didalam sebuah perjanjian tidak dapat terpenuhi sebagaimana mestinya.

Dalam hal ini, bentuk tanggung jawab sosial lingkungan perusahaan seperti halnya penjelasan diatas dapat dilaksanakan melalui dua cara yang lazimnya dilakukan oleh perseroan, yakni melalui kemitraan maupun non kemitraan, dengan menyalurkan bentuk pertanggungjawaban perusahaan bersama dengan pihak - pihak yang menjadi sasaran didalam mengalokasikan bantuan dari bentuk CSR perusahaan tersebut. Dengan ini, sudah barang tentu bahwasannya telah ada keterkaitan antara kedua belah pihak melalui nota kesepahaman atau perjanjian kerjasama yang dilakukan sebelumnya, dengan secara tertulis diantara para pihaknya. Dengan menterkaitkan hubungan sebuah perjanjian mengenai penyaluran CSR perusahaan terhadap yang menjadi sasaran
CSR tersebut, melalui sebuah perjanjian yang bentuknya tertulis dan disepakati para pihaknya dengan sejauh mana unsur dari bentuk kepatutan dan kewajaran pada Pasal 74 ayat (2) UUPT dapat terpenuhi dan tergambarkan didalam klausa perjanjian tersebut, juga sejauh mana pengaturan terhadap kepatutan dan kewajaran didalam penyaluran CSR perusahaan memaknai tolak ukur penerapan CSR perusahaan ditinjau dari aspek jumlahnya, sasarannya, dan penerapan pada bentuk perjanjiannya. Tulisan ini akan membahas makna "kepatutan dan kewajaran" dalam ketentuan Pasal 74 ayat (2) Undang - Undang Nomor 40 Tahun 2007 tentang Perseroan Terbatas ditinjau dari aspek jumlah, sasaran, dan bentuknya terhadap pelaksanaan perjanjian tanggung jawab sosial perusahaan.

\section{METODE}

Kajian inimenggunakanmetodeyuridis normative denganpendekatanperundang-undangan, konsep dan studikasus. Bahanhukum primer yang digunakandalampembahasanadalahUndangUndang No.40 Tahun 2007 tentang Perseroan Terbatas. Selainitu juga digunakan beberapa peraturan diantaranya: PeraturanPemerintah Nomor 47 Tahun 2012 tentang Tanggung Jawab Sosial dan Lingkungan Perseroan Terbatas, Kitab Undang-Undang Hukum Perdata, Peraturan Menteri BUMN Nomor PER - 03/MBU/12/2016 tentang Perubahan atas Peraturan Menteri Badan Usaha Milik Negara Nomor PER - 09/MBU/7/ 2015 tentang Program Kemitraan dan Program Bina Lingkungan Badan Usaha Milik Negara.

\section{HASIL DAN PEMBAHASAN}

Bentuk atas "Kepatutan dan Kewajaran" pada ketentuan Pasal 74 ayat (2) Undang Undang Nomor 40 Tahun 2007 tentang Perseroan Terbatas.

Penjelasan mengenai makna yang tertuang atas "kepatutan dan kewajaran" ini pada UUPT dijelaskan dengan makna "cukup jelas", dimana sebenarnya makna dan bentuk dari sebuah "kepatutan dan kewajaran" itu sendiri merupakan hal yang sifatnya universial. Banyak penafsiran yang akan berbeda - beda setiap pemaknaannya. Perusahaan bisa saja menganggap bahwasannya pelaksanaan CSR yang mereka salurkan sudah sesuai dengan "kepatutan dan kewajaran" yang 
dimaksudkan oleh undang - undang, namun hal tersebut dapat dianggap berbeda dan tidak memenuhi bentuk dan pemaknaan dari kepatutan dan kewajaran tersebut oleh masyarakat, karena belum atau tidak adanya sejauh mana acuan dan tolak ukur sebuah kepatutan dan kewajaran terkait dengan pelaksanaan CSR sebuah perusahaan. UUPT tidak memberikan standar atas pelaksanaan CSR yang berdasarkan atas kepatutan dan kewajaran itu sendiri, UUPT juga tidak menjelaskan sejauh mana sanksi akibat dari tidak terlaksanakannya CSR oleh sebuah perusahaan. Regulasi ini akan menyulitkan jika Pemerintah adalah pihak yang menetapkan standar kepatutan tersebut, karena untuk mencapai regulasi yang berkeadilan, Pemerintah harus menetapkan standar kepatutan tersebut dengan variasi yang berbeda-beda karena adanya ukuran perusahaan, kondisi kemampuan keuangan, kondisi stakeholder perusahaan, rencana pengembangan perusahaan dan kondisi perekonomian baik secara mikro maupun makro.

Pemaknaan terhadap bentuk kepatutan dan kewajaran, yang tertuang pada Pasal 74 ayat (2) UUPT, “Tanggung Jawab Sosial dan Lingkungan sebagaimana dimaksud pada ayat (1) merupakan kewajiban Perseroan yang dianggarkan dan diperhitungkan sebagai biaya Perseroan yang pelaksanaannya dilakukan dengan memperhatikan kepatutan dan kewajaran". Dengan menggungakan metode pendekatan secara argumentum a contrario, bahwasannya sebuah pelaksanaan tanggung jawab sosial perusahaan apabila pelaksanaannya tidak dirasa "patut dan wajar" maka penilaian terhadapnya berdasarkan ketentuan UUPT ini dianggap bukan merupakan sebuah perwujudan dari penerapan CSR perusahaan itu sendiri. Sehingga perlu untuk diketahui bentukan yang dimaksud oleh UUPT terkait kepatutan dan kewajaran sebuah CSR itu sejauh mana dan seperti apa nantinya didalam pelaksanaan.

Kepatutan itu sendiri menurut Kamus Besar Bahasa Indonesia (KBBI) merupakan kesesuaian atau kecocokan, dimana dimaksudkan atas segala yang kita lakukan hendaknya sesuai dengan batas - batas yang berlaku di masyarakat. Menurut Mariam Darus,kepatutanadalah yang dapatdirasakansebagaisopan,patut dan adil. Jadi rumus kewajarandan kepatutan meliputisemua yangdapat ditangkap, baik dengan intelek maupun perasaan".
Disisi lain, menurut Riduan Syahrini, mengartikan kepatutan ialah (Riduan Syahrini, 2015:206)kepatutan (billijkheid)adalah keadilan, keseimbangan membagikan keuntungan diantara pihak - pihak yang berkepentingan".

kepatutan yang dimaksud Riduan Syahrini disini ialah, kepatutan yang merupakan perpanjangan daripada azas itikad baik pada ketentuan yang tertuang akan KUHPerdata. Dimana kepatutan yang dimaksudnya merupakan sebuah bentukan yang adil dan seimbang diantara para pihaknya yang saling mengikatkan diri atas sebuah kepentingan.

Kepatutan yang merupakan salah satu azas yang terdapat pada hukum keperdataan. Asas kepatutan itu sendiri mengikat tidak hanyakarenaundang-undang menunjuknya, melainkan karena kepatutan itu menentukan isi dari janji itu mengikat. Asas kepatutan yang termuat dalam Pasal 1339 KUHPerdata menyebutkan bahwa suatu perjanjian tidak hanya mengikat untuk hal - hal yang dengan tegas dinyatakan di dalamnya, tetapi juga termasuk untuk segala sesuatu yang menurut sifat perjanjian diharuskan oleh kepatutan itu sendiri. Asas kepatutan di sini berkaitan dengan ketentuan mengenai isi perjanjian yang dibuat. Asas ini merupakan ukuran terhadap hubungan yang ditentukan juga oleh rasa keadilan yang hidup di masyarakat. Isi perjanjian yang dimaksudkan adalah apa saja yang dituangkan dan dinyatakan secara tegas oleh kedua belah pihak mengenai hak dan kewajiban mereka masing - masing di dalam perjanjian tersebut. Kepatutan dalam Pasal 1339 KUH Perdata, yang secara bersama - sama dengan kebiasaan dan undang - undang harus memperhatikan para pihak dalam melaksanakan perjanjiannya. Hal kepatutan dalam pelaksanaan perjanjian berada pada itikad baiknya, sekedar itikad baik ini memenuhi unsur subjektif, terletak pada hati sanubari orang-orang yang memiliki kepentingan, sedangkan kepatutan yang mempunyai unsur objektif, terletak terutama pada hal keadaan sekitar atas persetujuan tersebut yakni hubungannya dengan norma dan pandangan di masyarakat sekitar.

Berdasarkan ketentuan diatas, dapat dilihat bahwasannya kepatutan yang dimaksud disini ialah kepatutan yang sifatnya merupakan keadilan atau keseimbangan sehingga menciptajan suatu kesesuaian, yang dirasa baik dan tidak melanggar ketentuan serta pandangan kebiasaan yang baik 
dan tumbuh berkembang di masyarakat. Bentuk patut itu sendiri apabila dikaitkan dengan sebuah bentuk perjanjian, maka yang menjadi titik berat adalah objek yang didalam sebuah perjanjian tersebut merupakan hal atau objek yang bernilai patut atas pandangan kemasyarakatan dan patut pula terhadap pandangan hukum positif yang ada.

Selanjutnya mengenai pemaknaan atas bentuk dari sebuah "kewajaran", menurut Kamus Besar Bahasa Indonesia, memiliki makna kata dasar wajar yakni tidak menyimpang atau menyalahi dari sebuah ketentuan yang ada, atau dengan kata lain wajar adalah sesuatu yang dianggap dan dipersepsikan tentang hal yang semestinya. Wajar sendiri yang dimaksudkan ialah lebih memberikan pengertian terhadap subjek atau kata sifat, sedangkan kewajaran sendiri merupakan gambaran dari sebuah makna yang menjurus kepada sebuah objek atau kata yang memiliki maksud menunjuk pada sebuah objek. Sehingga menurut KBBI kewajaran atau yang merupakan kata dasar wajar ialah suatu hal yang memang semestinya dan tidak melanggar atas ketentuan yang ada.

Kewajaran atau wajar, disisi lain juga dijelaskan sebagai sebuah perbuatan atau aktivitas yang sudah selayaknya, sudah seharusnya dilakukan oleh seseorang, baik yang menyangkut akan diri sendiri, orang lain pada sebuah situasi (berkaitan dengan waktu), dan kondisi (berkaitan dengan tempatnya) tertentu. Sehingga pemaknaan atas sebuah kewajaran merupakan hal yang dinamis, tergantung dari sudut mana dipandang dan dipersepsikan. Untuk itu penulis menggambarkan bahwasannya persepsi terkait kewajaran merupakan hal yang dinamis, tergantung dari mana kewajaran itu dipahami atau dinilai, baik untuk kewajaran terhadap perbuatan atas orang atau subjeknya, waktunya, maupun tempatnya. Keseluruhan perbuatan tersebut dihubungan dengan arti dasar pemaknaan dari wajar dan atau kewajaran, yakni keseluruhan tindakan atau perbuatan yang berdasarkan subjek orangnya, waktunya, atau tempatnya yang sesuai dengan hal yang berimbang dan perlakuannya memang harus dilakukan sebagaimana mestinya serta atas hal tersebut tidak melanggar akan ketentuan yang sudah ada atau melanggar perundangan yang berlaku.

Perseoran atau perusahaan yang dimaksud pada Undang - Undang Nomor 25 Tahun 2007 tentang Penanaman Modal ini adalah jenis perusahaan yang bergerak di bidang perdagangan, jasa, dan ataupun manufaktur, yang pada intinya merusahaan tersebut tunduk juga terhadap aturan perundangan ini. Dengan demikian, jenis perusahaan yang berkegiatan dengan alam atau sumber daya alam menjadi lex specialis terhadap UUPT khususnya pada Pasal 74 jo. terhadap PP Nomor 47 Tahun 2012.

Untuk itu, terhadap perusahaan yang bergerak atas jenis kegiatannya masing - masing diatas, dapat dilihat bahwasannya jenis perusahaan yang pelaksanaan tanggung jawab sosialnya tunduk pada perundangan yang mana. Untuk perusahaan yang bergerak di bidang ekstraktif, agraris, dan atau manufaktur kembali ditegaskan pada penjelasan Pasal 5 PP Nomor 47 Tahun 2012 yang didalam melaksanakan bentuk tanggung jawab sosial, perusahaan tersebut harus memperhatikan kepatutan dan kewajaran. Kepatutan dan kewajaran yang dimaksud pada peraturan pemerintah ini berbunyi : yang dimaksud dengan kepatutan dan kewajaran adalah kebijakan perseroan, yang disesuaikan dengan kemampuan keuangan perseroan, dan potensi resiko yang mengakibatkan tanggung jawab sosial dan lingkungan harus ditanggung oleh Perseroan sesuai dengan kegiatan usahanya yang tidak mengurangi kewajiban sebagaimana yang ditetapkan dalam ketentuan peraturan perundang - undangan yang terkait dengan kegiatan usaha perseroan".

Sehingga dapat dimaknai bahwasannya, kepatutan dan kewajaran yang dimaksudkan pada penjelasan Pasal 5 PP Nomor 47 Tahun 2012 ini patut dan wajar terhadap pelaksanaan tanggung jawab sosial perusahaan atas penerapannya akan kebijakan perseroan yang disesuaikan dengan kemampuan keuangan perusahaan dan potensi resiko dari dan atas kegiatan perusahaan, karena usaha dan bentuk kegiatan perusahaan yang bersinggungan atau berkaitan dengan sumber daya alam baik secara langsung maupun tidak langsung. Untuk itu patut kiranya melihat dari sebuah pemaknaan atas bentuk suatu kepatutan dan kewajaran yang dituangkan kedalam sebuah perjanjian atas penyaluran kewajiban tanggung jawab sosial perusahaan, seperti apa dan bagaimana agar jelas serta dapat memenuhi kriteria bentuk yang dimaksud patut dan wajar, serta dapat diterima oleh masyarakat, dan tidak melanggar ketentuan perundang - undangan yang berlaku. Kepatutan dan kewajaran yang 
bagaimana yang dapat memberikan sebuah kepastian dan tidak menimbulkan penafsiran yang sedapat mungkin memiliki kesepemahaman yang sama.

Selain itu, kepastian hukum suatu peraturan sebagai hukum tertulis harus memenuhi syaratsyarat antara lain (Bagir Manan, 1994:6):

1. Jelas dalam perumusannya (unambiguous)

2. Konsisten dalam perumusannya (baik secara intern maupun ekstern). Konsisten secara intern mengandung makna bahwa dalam peraturan perundang-undangan yang sama harus terpelihara hubungan sietematik antara kaidah - kaidahnya, kebakuan susunan dan bahasa. Konsisten secara eketern, adalah adanya hubungan "harmonisasi" antara berbagai peraturan perundangundangan;

3. Penggunaan bahasa yang tepat dan mudah dimengerti.

Bahasa dalam peraturan perundangan haruslah menggunakan bahasa yang umum dipergunakan masyarakat. Tetapi ini tidak berarti bahasa hukum tidak penting, bahasa hukum baik dalam arti struktur, peristilahan, atau cara penulisan tertentu harus dipergunakan secara ajeg karena merupakan bagian dan upaya menjamin kepastian hukum. Asas kepastian hukum dapat dilihat dari terpenuhinya unsur-unsurberikut, yaitu: (a) lex scripta (harus tertulis), (b) lex stricta (ketat, tegas, larangan analogi), dan (c) lex certa (harus jelas atau tidak multitafsir).

Pemaknaan akan bentuk dari sebuah "kepatutan dan kewajaran" yang dijelaskan pada Pasal 74 ayat (2) UUPT belum dapat memberikan dan mencerminkan suatu kepastian hukum yang merupakan ciri utama dari hukum itu sendiri. Hal ini karena tidak terpenuhinya unsur lex stricta, dan lex certa, terbukti terhadap makna tersebut masih menimbulkan kebingungan dan keambiguan apa sebenarnya yang tergolong ke dalam "kepatutan dan kewajaran" yang dimaksud dari Pasal 74 ayat (2) UUPT tersebut. Mengingat dalam hal ini hukum harus mengatur secara pasti, dan jelas serta tegas, sehingga benar-benar dapat dilaksanakan dan diterapkan dalam pelaksanaannya atas penyaluran tanggung jawab sosial perusahaan.

Terhadap kepatutan dan kewajaran yang dimaksudkan dalam Pasal 74 ayat (2) belum menunjukkan sebuah kepastian hukum, terdapat multi tafsir dalampelaksanaan dari kata kepatutan dan kewajaran. Penjelasan pada Pasal 5 PP Nomor 47 Tahun 2012 yang menjelaskan bahwa kepatutan dan kewajaran yang dimaksudkan merupakan yang disesuaikan dengan tujuan dan kemampuan dari sebuah perusahaan, dimana terhadap kesesuaian yang bagaimana dan kemampuan yang seperti apa akan berbeda - beda pada setiap perseroan atau perusahaan yang akan melaksanakan sebuah bentuk tanggung jawab sosialnya. Sehingga dengan tidak adanya sebuah kepastian seperti apa bentuk terhadap pelaksanaan, tata cara, proses sebelum dan sesudah pelaksanaan, serta bentuk sasaran yang bagaimana yang dapat mencerminkan sebuah kepastian hukum terhadap bentuk dari kepatutan dan kewajaran yang dimaksud tersebut.

Seyogyanya terhadap kepastian hukum didalam ketentuan pasal ini mengatur sejauh mana bentukan dari patut dan wajar yang dimaksudkan, patut dan wajar yang diimplementasikan kepada sebuah ketentuan lebih lanjut mengenai bentuk penyaluran CSR perusahaan yang memenuhi ketentuan patut dan wajar sebagai tolak ukur yang pasti didalam perusahaan akan melaksanakan CSR-nya. Menurut penulis, terhadap kepatutan dan kewajaran, bentuk atas penafsirannya sangat dipengaruhi pula oleh pandangan masyarakat. Kepatutan dan kewajaran sendiri sejatinya berdasarkan penjelasan diatas, merupakan suatu hal akan sifatnya yang dapat dipandang dan dikembalikan kepada sudut pandang masyarakat. Pandangan pemerintah menilai sejauh mana pelaksanaan CSR perusahaan berdasarkan pandangan yang objekif, dengan perusahaan melaksanakan tanggung jawab sosialnya sesuai dengan kemampuan, manajemen resiko perusahaan, dan tujuan dari perusahaan itu sendiri dapat terlaksana dengan baik dan sesuai dengan ketentuan perundangan yang berlaku sudah merupakan salah satu yang dapat "menggugurkan" tanggung jawab sosial perusahaan karena pelaksanaannya dan juga terhadap kepatutan dan kewajarannya dianggap telah sesuai dan memenuhi. Lain halnya apabila pandangan subjektif dari masyarakat yang menilai dan merasakan dampak langsung dari pelaksanaan sebuah CSR perusahaan, belum tentu terhadap pandangan masyarakat yang relatif, pelaksanaan sebuah CSR perusahaan telah dan sudah dianggap memenuhi ketentuan Pasal 74 ayat (2) terkait patut dan wajar yang dimaksud. Pandangan dari masyarakat seharusnya juga menjadi salah satu 
tolak ukur dimana tidak hanya sebuah perusahaan "menggugurkan" tanggung jawab sosialnya dengan sebuah pelaksanaan yang sesuai dengan ketentuan yang berlaku, namun terhadap dampak atau hasil dari penyaluran CSR perusahaan tersebut haruslah sesuai dengan tingkat keberhasilan dan kepuasan dimasyarakat. Dengan tidak adanya patokan atau tolak ukur yang pasti inilah, pencapaian dan keberhasilan sebuah penyaluran CSR perusahaan kepada masyarakat menjadi abstrak bentuknya dan dapat memberikan tingkat pandangan akan gambaran yang berbedabeda. Disisi lain, terhadap penerapan akan penyaluran CSR juga berbeda-beda terhadap nilai dan kearifan di setiap wilayah yang berbeda - beda pula, sepertihalnya daerah satu dengan daerah lainnya di indonesia, berbeda bentuk, cara, dan sistematika pemberian CSR di setiap daerah dikarenakan perbedaan wilayah topografi, budaya, sosial masyarakat dan kesenjangan di setiap daerah yang berbeda-beda, sehingga terkait dengan tolak ukur pelaksanaan CSR perusahaan, pemerintah pusat juga mengikutsertakan dan memberikan kewenangan kepada pemerintah daerah masing-masing untuk memberikan batasan nilai dan tata cara pelaksanaan CSR.

\section{Kepatutan dan Kewajaran dipandang dari sudat Jumlah}

Terhadap perusahaan yang bergerak di bidang sumber daya alam dan bersinggungan langsung dengan sumber daya alam, tunduk pada ketentuan Pasal 74 UUPT dan PP Nomor 47 Tahun 2012 tentang Tanggung Jawab Sosial Perusahaan, terhadap jumlah yang dianggap patut dan wajar, dapat dijabarkan bahwasannya patut dan wajar terhadap jumlahnya berdasarkan ketentuan Undang-Undang BUMN dalam Pasal 2 jo. Pasal 66 ayat (1) Undang-Undang Nomor 19 Tahun 2003 jo. Pasal 8 Keputusan Menteri Negara BUMN Nomor 236 Tahun 2003 jo. Pasal 8 angka (4) Peraturan Menteri BUMN Nomor PER - 03/MBU/12/2016 tentang Perubahan atas Peraturan Menteri Badan Usaha Milik Negara Nomor PER - 09/MBU/7/2015 tentang program kemitraan dan program bina lingkungan Badan Usaha Milik Negara, dapat diberikan acuan sebesar 1 (satu) hingga 4\% (empat persen) dari hasil bersih laba perusahaan setiap akhir pembukuan dari sebuah perusahaan. Hal ini ditujukan kepada jenis perusahaan yang berada dinaungan BUMN saja, namun terhadap perusahaan yang tidak berstatus BUMN, peemerintah belum memberikan pengaturan yang pasti terkait seberapa besar acuan harus mengeluarkan jumlah dari CSR perusahaannya, karena berbeda setiap kekuatan dan kemampuan dari sebuah perusahaan - perusahaan yang diluar naungan BUMN tersebut.

Patut dan wajar dalam bentuk jumlah dan jenisnya, berdasarkan jumlah yang diberikan patut dan wajar terimplisitkan sebagai jumlah dan ketentuan pengeluaran yang dikeluarkan oleh perusahaan sebagai bentuk CSR haruslah sesuai proporsinya dengan tidak bertentangan dengan ketentuan yang diatur oleh perundangan, sedangkan dari sudut jumlah dalam jenisnya terhadap patut dan wajar yakni jenis objek atau bentuk daripada jumlah yang dikeluarkan perusahaan untuk penyaluran CSR dapat dilakukan atas bentukannya sebagai dana atau uang dan juga barang atau benda, selama peruntukannya sesuai dengan prinsip pengelolaan dan pelaksanaan CSR serta tidak melanggar norma - norma maupun perundang - undangan yang berlaku.

\section{Kepatutan dan Kewajaran dipandang dari sudat Sasaran}

Terhadap kepatutan dan kewajaran yang dipandang dari sudut sasaran atau tujuan dari sebuah pelaksanaan CSR perusahaan ini, merunut kembali atas bentuk kepatutan terhadap sasaran yakni, sasaran yang tepat guna berdasarkan gambaran yang dipetakan oleh Wibisono Yusuf (2007) dimana patut disini diartikan sebagai hal yang adil yakni sesuai dengan kebutuhan, sehingga kepatutan dapat dimaknai didalam sasaran yang dituju oleh CSR perusahaan tersebut benar - benar sasaran berupa subjek sosialnya maupun lingkungannya yang berdampak langsung dari segala aktivitas perusahaan dan memang dirasa kebutuhannya sesuai dengan kebutuhan yang ada, kebutuhan yang sesuai dengan kemampuan dan tujuan prioritas CSR perusahaan berdasarkan penjelasan Pasal 5 PP Nomor 47 Tahun 2012, patut yang menggambarkan kesesuaian atas suatu CSR yang disalurkan pada sasaran yang memang membutuhkan ialah menjadi tujuan utama terselenggarakannya CSR peusahaan tersebut, berdasarkan tinjauan yang sesuai dengan utama kebutuhan lingkungan di sekitar areal perusahaan. 
Terhadap bentuk dan pemaknaan atas kewajaran terhadap sasaran atau yang menjadi tujuan dari sebuah CSR perusahaan, ialah suatu bentuk kepada sasaran yang memang sudah selayaknya dan seharunya diberikan sebuah penyaluran CSR perusahaan. Atas sasaran yang menjadi tujuan tersebut dipandang memang seharusnya diberikan sesuai dengan menajemen potensi resiko perusahaan dan atas penyaluran tersebut sesuai dengan ketentuan yang ada ataupun tidak melanggar akan norma - norma maupun terhadap perundang - undangan yang berlaku. Untuk itu terhadap kepatutan dan kewajaran atas sasaran CSR itu sendiri, yakni haruslah memenuhi unsur sasaran yang sesuai dengan kebutuhan dan terhadap sasaran tersebut yang memang selayaknya mendapatkan.

\section{Kepatutan dan Kewajaran dipandang dari sudat Bentuk Perjanjian}

Berdasarkan bentuk perjanjian terhadap penyaluran CSR perusahaan yang berbentuk perjanjian tertulis baik otentik maupun dibawah tangan, dalam keterkaitannya terhadap ketentuan Pasal 74 ayat (2) UUPT dimaknai bentuknya sebagai suatu hal yang berdasarkan kepatutan dan kewajaran. Terhadap bentuk perjanjian penyaluran CSR perusahaan berdasarkan kepatutan yakni bentuk perjanjian dengan bentuk yang otentik maupun dibawah tangan yang memiliki unsur kesesuaian dengan peraturan yang berlaku, kesesuaian dengan tujuan serta anggaran dasar perusahaan, dan juga kesesuian bahwasannya tujuan pembentukan perjanjian pelaksanaan CSR perusahaan ini secara tertulis dimaksudkan sebagai alat pembuktian yang adil bagi para pihaknya. Sedangkan kewajaran dipandang dari sudut pandang bentuk perjanjian, yakni yang sudah selayaknya atau sepantasnya atas perjanjian yang bentuknya secara tertulis ini dibuat, sehingga dapat memberikan "pegangan" bagi para pihaknya berupa kepastian hukum dan perlindungan hukum nantinya pada para pihak yang saling mengikatkan dirinya.

\section{Analisis bentuk kepatutan dan kewajaran atas perjanjian kemitraan CSR Perusahaan}

Dalam pemenuhan suatu perjanjian dalam suatu perikatan yang memberikan sebuah keadilan dan keseimbangan bagi para pihaknya, berdasarkan ketentuan dan aturan yang berlaku. Herlin Boediono memaparkan bahwa sebaik - baiknya perjanjian ialah yang seyogyanya memberikan akibat timbal - balik yang seimbang bagi para pihaknya. Analisis penulis terhadap perjajian pelaksanaan CSR oleh PT. Pertamina (Persero) diatas, yang dimaksudkan dengan memberikan akibat timbal balik yang seimbang ialah dimana salah satu pihak mendapatkan prestasi dan disisi lain pihak yang memberikan sebuah prestasi. Prestasi ini sendiri haruslah sesuai dan tidak bertentangan dengan ketentuan yang berlaku. Dianggap seimbang apabila salah satu pihak dan pihak lainnya sama - sama merasa tidak dirugikan dan masing - masing akan hak dan kewajibannya terpenuhi dengan tertuang didalam sebuah perjanjian. Perjanjian tersebut juga haruslah dibuat dengan memperhatikan kepatutan dan kewajaran didalam pembuatannya, bagi penulis ketentuan yang ada serta pengimplementasian sebuah kewajiban CSR perusahaan tertuang dengan baik pada jenis perjanjian CSR kemitraan ini. Dimana pihak pemberi prestasi yakni PT. Pertamina (Persero) memberikan kewajibannya berupa penyaluran dana CSR untuk pengelolaan eks taman SPBU, dimana sebagai haknya yakni PT. Pertamina (Persero) telah melaksanakan kewajibannya sebagai perusahaan didalam menyalurkan bentuk tanggung jawab sosial lingkugnannya. Disisi lain sebagai sasaran atau pihak yang menjadi penerima prestasi, yakni yang diwakili oleh Pemerintah Kota Surabaya, mendapatkan prestasi berupa bantuan dana CSR yang salah satu tujuannya untuk melestarikan lingkungan di wilayah sektor Pemerintahan Kota Surabaya. Dengan kata lain, penerapan timbal balik dalam perjanjian ini telah mencerminkan apa yang dimaksud bahwasannya sebuah perjanjian seyogyanya mencerminkan dan menggambarkan keseimbangan dan hubungan timbal balik diantara para pihaknya. Sebagai perseroan yang wajib melaksanakan sebuah CSR perusahaan, PT. Pertamina (Persero) melaksanakan sebuah prestasi berupa penyaluran CSR perusahaan, dan pihak Pemerintah Kota Surabaya menerima prestasi akan penyaluran CSR tersebut.

\section{Analisis bentuk kepatutan dan kewajaran atas perjanjian non kemitraan CSR Perusahaan}

Pada perjanjian penyaluran CSR PT. PJB ini, masih ada beberapa kekurangan, terkait dengan tidak jelasnya batas hak - hak dan kewajiban dari 
masing - masing pihak, cara penyerahan objek CSR, serta alternatif penyelesaian sengketa apabila terjadi permasalahan di kemudian hari, namun berdasarkan analisis penulis atas kepatutan dan kewajaran pada bentuk perjanjian ini, tetap sah dan berlaku serta mengikat para pihaknya karena berdasar azas kebebasan berkontrak para pihak bebas menentukan apa yang menjadi keinginan meraka pada sebuah perjanjian, namun tetap mengindahkan batasan - batasan yang ada. Serta pada perjanjian ini, menurut unsur dan kualifikasi berdasarkan Perda Nomor 14 Tahun 2012 tentang Tanggung Jawab Sosial Perusahaan, perjanjian CSR dalam bentuk hibah ini dapat dikategorikan sebagai bentuk penyaluran CSR perusahaan (PT. PJB) dengan cara non kemitraan, walaupun sepatutnya hubungan langsung kepada masyarakat didalam pelaksanaannya, namun dalam hal ini diwakili oleh pemerintah daerah yakni pemerintah Kota Surabaya, sebagai pihak yang sah mewakili masyarakat didalam PT. PJB melaksanakan penyaluran hibah bantuan CSR-nya.

Berdasarkan analisis diatas, dikaitkan terhadap teori perjanjian yang dikemukakan oleh Herlin Budiono, dimana perjanjian sedapat mungkin dapat dan seyogianya menguntungkan pihak secara timbal balik. Terhadap sebuah perjanjanjian penyaluran CSR oleh perusahaan PT. Pertamina (Persero) dan PT. Pembangkitan Jawa Bali (PJB), unsur timbal balik dalam substansi sebuah perjanjian sudah dapat terpenuhi, seperti halnya dengan melaksanakan perjanjian ini, perusahaan yang menyalurkan CSRnya telah melaksanakan kewajiban terhadap tanggung jawabnya mengeluarkan dana bantuan CSR kepada sosial lingkungan masyarakatnya, sedangkan disisi lain penerima penyaluran CSR juga mendapatkan manfaat dari pemberian CSR oleh perusahaan tersebut, dengan memperhatikan batasan patut dan wajar terhadap penyaluran CSR yang berdasarkan perjanjian tersebut terhadap jumlah bantuannya, sasaran kepada siapa bantuan tersebut tersaluarkan, dan bentuk perjanjian yang bagaimana sehingga nantinya dapat sama - sama memberikan kepastian dan perlindungan hukum bagi para pihaknya.

Untuk itu, pentingnya didalam membuat sebuah perjanjian, khususnya pada perjanjian yang merupakan pemenuhan kewajiban perusahaan akan pelaksanaan tanggung jawab sosial perusahaan, yang berimbang dan tidak memihak. Karena, terhadap pelaksanaan tanggung jawab perusahaan tersebut, perusahaan turut berkomitmen terhadap kemajuan dan pembangunan yang berkelanjutan sesuai dengan tujuan dan fungsi tanggung jawab sosial perusahaan. Sehingga pentingnya membuat sebuah perjanjian yang berimbang terkait pelaksanaan CSR untuk kesejahteraan dan kebaikan bagi masing - masing pihaknya.

Undang-Undang Perseroan Terbatas secara tegas tidak mengatur tentang sanksi bagi perusahaan yang tidak melaksanakan kewajibannya dalam memenuhi tanggungjawab sosialnya. Sehingga bagi perusahaan maupun bagi para pihak lain yang berkepentingan, dalam hal ini masih meraba - raba bagaimana bentuk dan baiknya sanksi yang sifatnya hukum publik, sedangkan pada bentuk akibat hukum terhadap perjanjian CSR dapat dibedakan terhadap penyalahan terkait wanprestasi maupun pada tindakan atau perbuatan melawan hukumnya.

Sanksicukupjelasterdapatdalam Perda Provinsi Jawa Timur Nomor 4 Tahun 2011 tentang Tanggung Jawab Sosial Perusahaan yang menyatakan bagi perusahaan yang tidak merencanakan, menetapkan, dan melaksanakan tanggung jawab sosialnya, berdasarkan Pasal 20 Perda ini, dikenakan berupa sanksi administratid berupa teguran secara tertulis.

Secara garis besar, belum adanya pengaturan secara jelas dan pasti terkait sanksi yang secara terperinci dan sedapatnya memberikan sebuah "ancaman" apabila perusahaan tidak melaksanakan tanggung jawab sosial dan lingkungannya. Ancaman terhadap komitmen perusahaan didalam turut serta melaksanakan bentuk tanggung jawab sosial lingkungannya dengan maksud agar perusahaan menjaga dan memperhatikan dengan baik komitmen terhadap pembangunan yang berkelanjutan dan berkesinambungan melalui program CSR ini. Sehingga apabila dengan adanya ketentuan yang pasti terkait dengan bentuk sanksi yang jelas nantinya, diharapkan pelaksanaan CSR perusahaan dapat seluruhnya terlaksana dan pelaksanaannya pun sesuai dengan ketentuan terhadap bentuk dan makna dari sebuah "kepatutan dan kewajaran" yang tersebut dalam Pasal 74 ayat (2) UUPT.

\section{SIMPULAN}

Kepatutandidasarkan pada keadilan atau keseimbangan, adakesesuaianataukeseimbangan 
antara kemampuan perusahaan terhadap resiko sebagai bentuk tanggung jawab sosial perusahaan. Kewajaran bermakna seharusnya atau sudah selayaknya dilakukan berdasarkan ketentutan dan aturan yang sesuai dan berlaku.Kepatutan dan kewajarandapatdilihatdarijumlah, sasaran, dan bentukperjanjian. Dilihatdari jumlahnya, pengeluaran yang dikeluarkan oleh perusahaan haruslah sesuai proporsinya, kekuatan perusahaan, serta tidak bertentangan peraturan. Dilihatdarisasarannyamaksudnyaharussesuaidengan prioritas perusahaan dalam penyaluranya, diberikan kepada yang berpotensiterkena resiko perusahaan dan tidak melanggar peraturan. Dari sudut bentuk perjanjiannya, adanya kesesuaian antaratujuan dan prospek pertanggung jawaban dari perusahaan dalam bentukannya sebagai

\section{DAFTAR RUJUKAN}

PT. Pembangkitan Jawa Bali, 2011, Laporan Keberlanjutan 2011, Jurnal Laporan Keuangan Perusahaan, Surabaya.

Syahrini,Riduan, 1999, Rangkuman Intisari Ilmu Hukum, Penerbit Citra Aditya Bakti, Bandung. 2015, Kata - Kata Kunci Mempelajari Ilmu Hukum, Bandung, Alumni.

Wibisono, Yusuf, 2007, Membedah Konsep dan Aplikasi CSR, Gresik, Frescho Publishing.

Kitab Undang - Undang Hukum Perdata (KUHPerdata).

Undang - Undang Nomor 19 Tahun 2003 tentang Badan Usaha Milik Negara, Lembaran Negara Republik Indonesia Tahun 2003 Nomor 70;

Undang - Undang Nomor 40 Tahun 2007 tentang Perseroan Terbatas, Lembaran Negara Republik Indonesia Tahun 2007 Nomor 106.

Undang-Undang Nomor 2 Tahun 2014 tentang Perubahan Atas Undang - Undang Nomor. 30 Tahun 2004 tentang Jabatan Notaris (UUJN), Lembaran Negara Republik Indonesia Tahun 2014 Nomor 5491;

Peraturan Pemerintah Nomor 47 Tahun 2012 tentang Tanggung Jawab Sosial dan Lingkngan Perseroan Terbatas, Lembaran Negara Republik Indonesia Tahun 2012 Nomor 89. perjanjian yang tertulis. Sedangkan kewajaran dipandang dari sudut pandang bentuk perjanjian, yakni yang sudah selayaknya perjanjian tertulis ini dibuat, sehingga dapat memberikan kepastian hukum dan perlindungan hukum nantinya pada para pihak.Selanjutnya terkait dengan akibat hukum apabila sebuah perjanjian atau pelaksanaan atas CSR perusahaan tidak terlaksana maupun pelaksanaannya tidak sesuai dengan bentuk atas kepatutan dan kewajaran, dalam hal ini pemerintah belum memberikan ketentuan sanksi yang secara jelas, terperinci, dan memberikan kepastian hukum nantinya, sehingga beberapa sanksi yang dapat diterapkan berasal dari ketentuan pelaksanaan peraturan yang ditetapkan oleh pemerintah di daerah / pemerintah daerah.

Keputusan Menteri Badan Usaha Milik Negara Nomor Kep-236/MBU/2003 tentang Program Kemitraan Badan Usaha Milik Negara Dengan Usaha Kecil dan Program Bina Lingkungan.

Peraturan Menteri BUMN Nomor PER - 03/ MBU/12/2016 tentang Perubahan atas Peraturan Menteri Badan Usaha Milik Negara Nomor PER - 09/MBU/7/2015 tentang program kemitraan dan program bina lingkungan Badan Usaha Milik Negara, Berita Negara Republik Indonesia Tahun 2016 Nomor 1928.

Peraturan Menteri BUMN Nomor PER - 02/ MBU/7/2017 tentang Perubahan Kedua atas Peraturan Menteri Badan Usaha Milik Negara Nomor PER - 09/MBU/7/2015 tentang program kemitraan dan program bina lingkungan Badan Usaha Milik Negara, Berita Negara Republik Indonesia Tahun 2017 Nomor 1002.

Peraturan Daerah Provinsi Jawa Timur Nomor 4 Tahun 2011 tentang Tanggung Jawab Sosial Perusahaan, Lembaran Daerah Provinsi Jawa Timur Nomor 4 Tahun 2011 Seri D.

Peraturan Gubernur Jawa Timur Nomor 52 Tahun 2012 tentang Petunjuk Pelaksanaan Peraturan Daerah Provisi Jawa Timur Nomor 4 Tahun 2011 tentang Tanggung Jawab Sosial Perusahaan. 